\title{
Spatial variability of photosynthetic production and ecosystem respi- ration on a hundred-kilometer scale within a Mongolian semiarid grassland
}

\author{
Tomoko NAKANO*, ${ }^{\dagger}$, and Masato SHINODA** \\ $\left(\begin{array}{c}* \text { Faculty of Economics, Chuo University, 742-1 Higashinakano, Hachioji, Tokyo 192-0393, Japan } \\ * * \text { Graduate School of Environmental Studies, Nagoya University, Furo-cho, Chikusa-ku, Nagoya 464-8601, Japan }\end{array}\right)$
}

\begin{abstract}
Grassland ecosystems cover a large area of the land surface and play an important role in the global carbon cycle. The objectives of this study were to examine the spatial variability of gross primary production $(G P P)$ and ecosystem respiration $\left(R_{\text {eco }}\right)$ within a semiarid grassland ecosystem and to evaluate the environmental factors that control the spatial patterns of carbon exchanges. We determined GPP and $R_{\text {eco }}$ using transparent and opaque closed chambers at nine grassland sites in central Mongolia during the summers from 2009 through 2011. To remove effects of temporal changes in radiation and temperature, GPP and $R_{\text {eco }}$ were fitted to light- and temperature-response curves. The fitting parameters (light-saturated GPP $\left[P_{\max }\right]$, apparent quantum yield $[\alpha]$, standardized $R_{\text {eco }}$ at $20{ }^{\circ} \mathrm{C}$ $\left[R_{20}\right]$, and the temperature sensitivity $\left[Q_{10}\right]$ of $\left.R_{\text {eco }}\right)$ were compared among the sites. The GPP and $R_{\text {eco }}$ parameters differed significantly among the sites. Spatial patterns of $P_{\max }$ and $R_{20}$ were highly correlated with plant aboveground green biomass $(A G B)$ and number of plant species. The $Q_{10}$ of $R_{\text {eco }}$ was significantly related to soil moisture. The light-saturated $G P P$ normalized to the amount of $A G B$ did not differ significantly among the sites, whereas the $R_{20}$ residuals of the linear biomass model were correlated with soil water content and carbon/nitrogen ratios. The results suggest that, within this semiarid grassland, spatial variations of $G P P$ are strongly controlled by $A G B$ and that variations in $R_{\text {eco }}$ are associated mainly with $A G B$ and secondarily with soil water content and soil nutrient condition.
\end{abstract}

Key words: Ecosystem respiration, Gross primary production, Mongolia, Semiarid grassland, Spatial variability.

\section{Introduction}

The exchange of $\mathrm{CO}_{2}$ between terrestrial ecosystems and the atmosphere is controlled by the balance between $\mathrm{CO}_{2}$ uptake during photosynthesis and $\mathrm{CO}_{2}$ emissions associated with plant and soil respiration. Physical and biological factors cause the spatial variability of these exchanges to be high. Several studies have used eddy covariance measurement networks to examine global and regional spatial variability of $\mathrm{CO}_{2}$

Received; November 5, 2013.

Accepted; March 29, 2014.

†Corresponding Author: nakanot@tamacc.chuo-u.ac.jp

DOI: 10.2480/agrmet.D-13-00026 exchanges. Kato and Tang (2008) compiled data collected from 49 flux towers in East Asia and assessed the spatial variability of ecosystem $\mathrm{CO}_{2}$ exchange for a variety of ecosystem types, including tundra, wetlands, grasslands, and forests. Yuan et al. (2009) used the AmeriFlux and EuroFlux datasets to characterize spatial patterns, relative to latitude, of the variations of mean annual carbon budgets between sites. Yu et al. (2013) analyzed spatial variation and environmental drivers of the carbon fluxes in different terrestrial ecosystems in China. These studies have demonstrated that annual rates of gross primary production $(G P P)$, ecosystem respiration $\left(R_{\text {eco }}\right)$, and net ecosystem $\mathrm{CO}_{2}$ exchange $(N E E)$ are significantly correlated with mean annual temperature and annual precipitation. 
However, recent studies have reported that smallerscale (from tens of meters to hundreds of kilometers) spatial variation of $\mathrm{CO}_{2}$ fluxes is very large, even within ecosystems in which climate and vegetation are similar. Maestre and Cortina (2003) reported a large variability in soil respiration when comparing patches with different soil surface features and different plant cover in a Mediterranean semiarid steppe in Spain. Risch and Frank (2006) measured $\mathrm{CO}_{2}$ fluxes at seven grassland sites in the northern winter range of Yellowstone National Park, USA, and found that there was a large amount of spatial variability in $\mathrm{CO}_{2}$ fluxes related to aboveground biomass and shoot nitrogen content. Ngao et al. (2012) determined soil respiration in seven plots in a European beech forest and discovered that the spatial variability was explained by soil bulk density, carbon/nitrogen ratio, and leaf area index. Accurate estimates of regional and global carbon budgets therefore require knowledge of the amplitude and understanding of the underlying causes of small-scale spatial variation in atmosphere-ecosystem $\mathrm{CO}_{2}$ exchanges.

In Mongolia, grasslands cover approximately $80 \%$ of the country. Grasslands are characterized by large spatial heterogeneity in soil texture and moisture, carbon and nitrogen content, and plant composition and production (Risch and Frank, 2006). However, spatial variability of $\mathrm{CO}_{2}$ fluxes within the Mongolian grassland ecosystem is still poorly understood. We have conducted $\mathrm{CO}_{2}$ flux observations in a semiarid grassland of Mongolia since 2004 and have reported the temporal changes in photosynthetic productivity and respiratory $\mathrm{CO}_{2}$ release (Nakano et al., 2008; Nakano and Shinoda, 2010). An important next step is examination of the spatial variability of $\mathrm{CO}_{2}$ exchanges in this grassland ecosystem. The objective of this study was to assess the spatial variability of ecosystem $\mathrm{CO}_{2}$ exchanges within a semiarid grassland in central Mongolia and to evaluate the dependence of plant photosynthesis and ecosystem respiration on the spatial variations of environmental parameters.

\section{Materials and Methods}

\subsection{Site description}

The measurements were conducted at nine sites in central Mongolia $\left(46.3-47.5^{\circ} \mathrm{N}, 105.9^{-}-108.1^{\circ} \mathrm{E}\right.$; elevation ranges from ca. 1000 to $1500 \mathrm{~m}$ above sea level) in the summers of 2009, 2010, and 2011 (Fig.1, Table 1). Sites BU-NG, BU-G1, and BU-G2 were located in Bayan Unjuul (BU) county and were within $1 \mathrm{~km}$ of each other. A $300 \mathrm{~m} \times 300 \mathrm{~m}$ area has been enclosed by a fence since June 2004 to prevent livestock from grazing (Shinoda et al., 2010). Site BU-NG was located inside that fence, and sites BU-G1 and BU-G2 were located outside the fence. Sites NB, SB1, and SB2 were located approximately $50 \mathrm{~km}$ north, $25 \mathrm{~km}$ south, and $40 \mathrm{~km}$ south of BU, respectively. Sites DT, BT, and BJ were located in grasslands near the villages of Delgertsogt (ca. $90 \mathrm{~km}$ south of BU), Bayantsagaan (ca. $100 \mathrm{~km}$ east of BU), and Bayanjargalan (ca. 170 $\mathrm{km}$ east of BU), respectively.

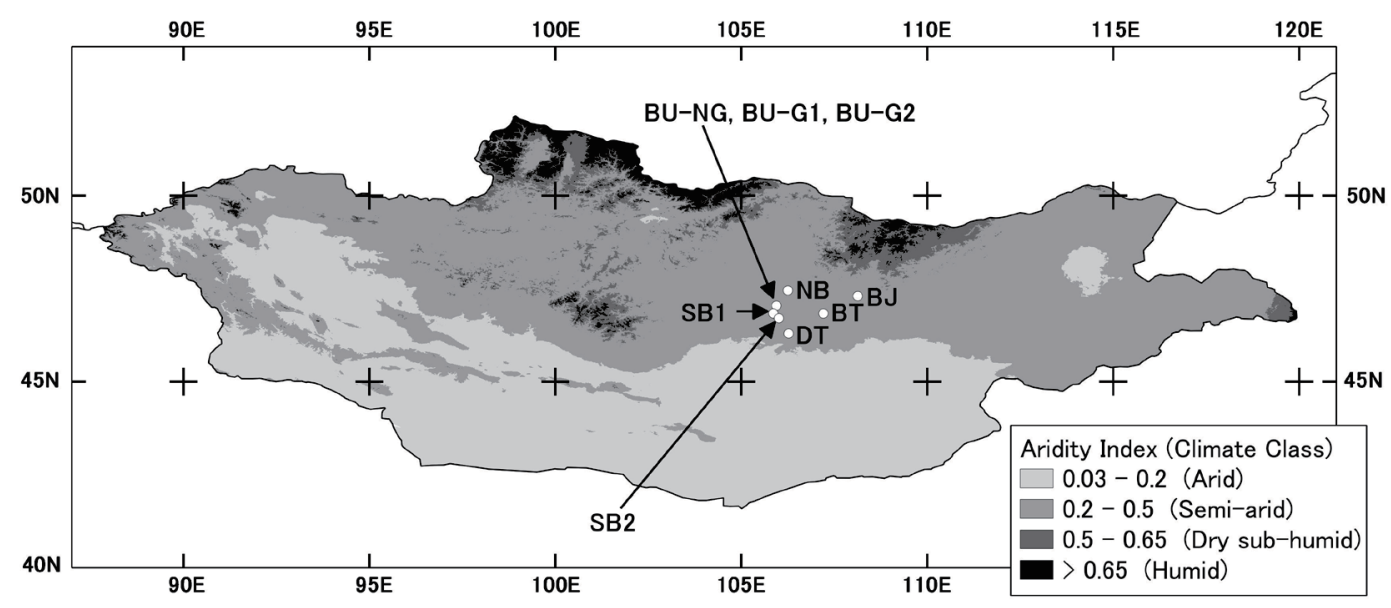

Fig. 1. Aridity indices and locations of the study sites in Mongolia. 
T. Nakano and M. Shinoda : Spatial variability of ecosystem $\mathrm{CO}_{2}$ exchange within a semiarid grassland

Table 1. Locations and climate statistics of the measurement sites.

\begin{tabular}{|c|c|c|c|c|c|c|}
\hline \multirow[b]{2}{*}{$\begin{array}{l}\text { Site } \\
\text { Sampling } \\
\text { date }\end{array}$} & \multicolumn{3}{|c|}{2009 August } & \multicolumn{3}{|c|}{2010 August } \\
\hline & $\begin{array}{c}\text { BU-NG } \\
\text { Aug. } 15-16\end{array}$ & $\begin{array}{c}\text { BU-G1 } \\
\text { Aug. 17-18 }\end{array}$ & $\begin{array}{c}\text { SB1 } \\
\text { Aug. 19-20 }\end{array}$ & $\begin{array}{c}\text { NB } \\
\text { Aug. } 15-16\end{array}$ & $\begin{array}{c}\text { BU-G2 } \\
\text { Aug. } 17-18\end{array}$ & $\begin{array}{c}\text { SB2 } \\
\text { Aug. 19-20 }\end{array}$ \\
\hline Latitude & $47^{\circ} 02^{\prime} 4^{\prime \prime} \mathrm{N}$ & $47^{\circ} 02^{\prime} 39^{\prime \prime} \mathrm{N}$ & $46^{\circ} 50^{\prime} 01^{\prime \prime} \mathrm{N}$ & $47^{\circ} 27^{\prime} 02^{\prime \prime} \mathrm{N}$ & $47^{\circ} 02^{\prime} 33^{\prime \prime} \mathrm{N}$ & $46^{\circ} 42^{\prime} 09^{\prime \prime} \mathrm{N}$ \\
\hline Longitude & $105^{\circ} 57^{\prime} 02^{\prime \prime} \mathrm{E}$ & $105^{\circ} 56^{\prime} 51^{\prime \prime} \mathrm{E}$ & $105^{\circ} 51^{\prime} 31^{\prime \prime} \mathrm{E}$ & $106^{\circ} 15^{\prime} 09^{\prime \prime} \mathrm{E}$ & $105^{\circ} 56^{\prime} 43^{\prime \prime} \mathrm{E}$ & $106^{\circ} 00^{\prime} 46^{\prime \prime} \mathrm{E}$ \\
\hline $\begin{array}{l}\text { Elevation } \\
(\mathrm{m})\end{array}$ & 1200 & 1200 & 1296 & 1507 & 1200 & 1351 \\
\hline Aridity index ${ }^{\dagger}$ & 0.24 & 0.24 & 0.23 & 0.34 & 0.24 & 0.24 \\
\hline $\begin{array}{l}\text { Mean air } \\
\text { temperature } \\
\text { during the } \\
\text { warmest } \\
\text { quarter } \\
\left({ }^{\circ} \mathrm{C}\right)^{\dagger \dagger}\end{array}$ & 17.2 & 17.2 & 17.2 & 15.2 & 17.2 & 16.8 \\
\hline $\begin{array}{l}\text { Precipitation } \\
\text { during the } \\
\text { warmest } \\
\text { quarter } \\
(\mathrm{mm})^{\dagger \dagger}\end{array}$ & 139 & 139 & 141 & 172 & 139 & 140 \\
\hline $\begin{array}{l}\text { Annual } \\
\text { maximum } \\
\text { NDVI }^{\dagger \dagger \dagger}\end{array}$ & 0.34 & 0.34 & 0.34 & 0.45 & 0.34 & 0.35 \\
\hline
\end{tabular}

\begin{tabular}{|c|c|c|c|}
\hline \multirow{3}{*}{$\begin{array}{l}\text { Site } \\
\text { Sampling date }\end{array}$} & \multicolumn{3}{|c|}{2011 July-August } \\
\hline & DT & BT & BJ \\
\hline & Jul. 30-31 & Aug. $1-2$ & Aug.3-4 \\
\hline Latitude & $46^{\circ} 17^{\prime} 29^{\prime \prime} \mathrm{N}$ & $46^{\circ} 49^{\prime} 56^{\prime \prime} \mathrm{N}$ & $47^{\circ} 17^{\prime} 56^{\prime \prime} \mathrm{N}$ \\
\hline Longitude & $106^{\circ} 16^{\prime} 20^{\prime \prime} \mathrm{E}$ & $107^{\circ} 12^{\prime} 19^{\prime \prime} \mathrm{E}$ & $108^{\circ} 07^{\prime} 55^{\prime \prime} \mathrm{E}$ \\
\hline Elevation (m) & 1391 & 1363 & 1464 \\
\hline Aridity index ${ }^{\dagger}$ & 0.22 & 0.27 & 0.36 \\
\hline $\begin{array}{l}\text { Mean air temperature } \\
\text { during the warmest } \\
\text { quarter }\left({ }^{\circ} \mathrm{C}\right)^{\dagger \dagger}\end{array}$ & 17.3 & 16.2 & 15.5 \\
\hline $\begin{array}{l}\text { Precipitation during } \\
\text { the warmest quarter } \\
(\mathrm{mm})^{\dagger \dagger}\end{array}$ & 129 & 157 & 200 \\
\hline $\begin{array}{l}\text { Annual maximum } \\
\text { NDVI }^{\dagger \dagger \dagger}\end{array}$ & 0.25 & 0.30 & 0.43 \\
\hline
\end{tabular}

\footnotetext{
${ }^{\dagger}$ Data were acquired from Global Aridity and PET database by CGIAR-CSI (see footnote 1).

† Data were acquired from the WorldClim Global Climate Data (Hijmans et al., 2005; see footnote 2).

${ }^{\dagger \dagger \dagger}$ Data are average values for the period 2001-2010 (see footnote 3).
} 


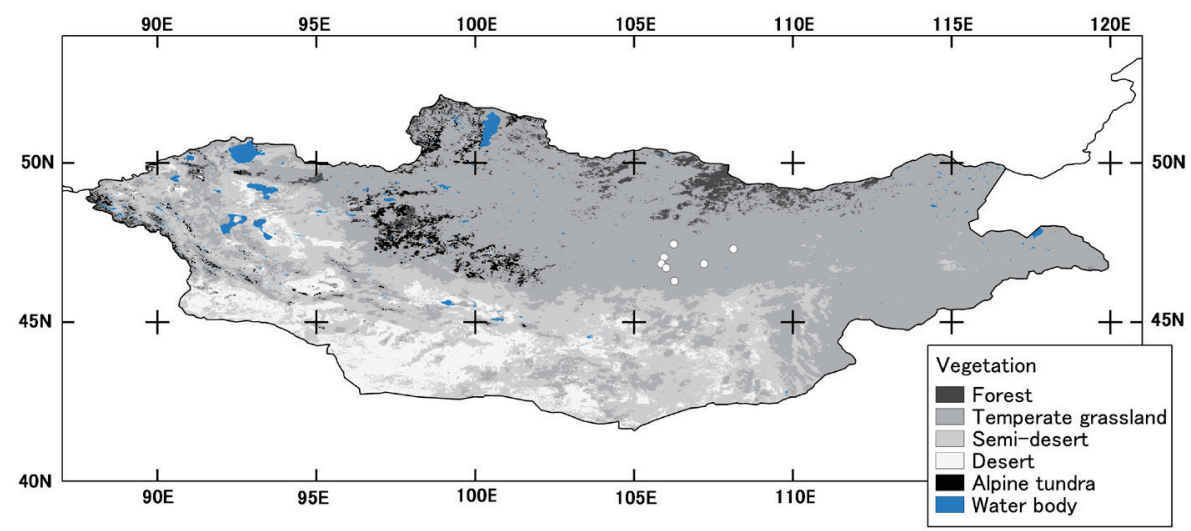

Fig. 2. Vegetation classification in Mongolia. Circles denote the study sites (same as Fig. 1).

The aridity index ${ }^{1}$, which is calculated from mean annual precipitation and mean annual potential evapotranspiration (PET), is generally used for climate classification and is a measure of the deficit of precipitation compared to atmospheric water demand (UNEP, 1997). Figure 1 indicates that all of the nine sites were located in a "semi-arid" climate according to the aridity index. Climatic values of mean air temperature and precipitation during the warmest quarter (JuneAugust $)^{2}$ are listed in Table 1 . The temperature and precipitation ranged from $15.2{ }^{\circ} \mathrm{C}$ at $\mathrm{NB}$ to $17.3{ }^{\circ} \mathrm{C}$ at DT and from $129 \mathrm{~mm}$ at DT to $200 \mathrm{~mm}$ at BJ, respectively. Table 1 also shows the annual maximum normalized difference vegetation index $(\mathrm{NDVI})^{3}$ averaged over the period 2001-2010. The data indicate that the NDVI was high at places where the precipitation was high, such as sites $\mathrm{NB}$ and $\mathrm{BJ}$, and low where the precipitation was low.

The vegetation ${ }^{4}$ in the area is classified as "temper-

\footnotetext{
${ }^{1}$ Data were downloaded from the Global Aridity and PET database by the Consultative Group on International Agricultural Research, Consortium for Spatial Information (CGIAR-CSI). URL: $\quad$ http://www.cgiar-csi.org/data/global-aridity-and-petdatabase.

${ }^{2}$ Data were downloaded from the WorldClim Global Climate Data (Hijmans et al., 2005). URL: http://worldclim.org/. The data are average values for the years 1950-2000.

${ }^{3}$ NDVI was calculated from the MODIS land surface reflectance dataset (MOD09A1) downloaded from the Land Processes Distributed Active Archive Center (LP DAAC), U.S. Geological Survey. URL: http://pdaac.usgs.gov. For details, refer to Nakano et al. (2013).

${ }^{4}$ Data were downloaded from the Global Mapping Home Page of the International Steering Committee for Global Mapping (ISCGM). URL: http://www.iscgm.org/.
}

ate grassland" (Fig. 2) and is grazed by livestock. The plant community is dominated by graminaceous perennial grasses (Agropyron cristatum, Cleistogenes squarrosa, and Stipa krylovii), annual forbs (Artemisia spp. and Chenopodium spp.), and small shrubs (Caragana spp.). Soils at the study sites are classified as Kastanozems (IUSS Working Group WRB, 2006), a type of soil that is widely distributed in the Mongolian grasslands.

\section{2 $\mathrm{CO}_{2}$ flux measurements}

We used a closed-chamber method to measure $\mathrm{CO}_{2}$ fluxes. The chamber was a cube, $0.4 \mathrm{~m}$ on a side and open on the bottom. All sides of the chamber were clear and made of transparent acrylic plates, which transmit about $94 \%$ of photosynthetically active radiation $(P A R)$. For each site, three or four stainless-steel collars were inserted $5 \mathrm{~cm}$ into the soil before the measurements were started. They remained in place for the duration of the measurements to allow repeated measurements to be made at the same location. The chamber was fitted with a soft rubber strip in the groove of the collar to create an airtight seal during measurements. A closed circuit connected the chamber to a $\mathrm{CO}_{2}$ analyzer (LI-7000, Li-Cor, Lincoln, NE, USA, in 2009; GMP343, Vaisala, Helsinki, Finland, in 2010 and 2011). The chamber was placed on the collar for $3 \mathrm{~min}$, and the $\mathrm{CO}_{2}$ concentration was recorded at 5 -s intervals using a datalogger (Thermic 2300A, Eto Denki, Tokyo, Japan). Net ecosystem $\mathrm{CO}_{2}$ exchange $(N E E)$ was calculated from the rate of change of the chamber $\mathrm{CO}_{2}$ concentration during the first $1 \mathrm{~min}$ of chamber closure. Positive and negative $N E E$ values correspond to $\mathrm{CO}_{2}$ emission and uptake, respectively, 
by the ecosystem. To measure daytime ecosystem respiration $\left(R_{\text {eco }}\right)$, an aluminum shroud was placed over the chamber to eliminate all light immediately after measurements were taken in the light. Gross primary production was calculated by subtracting $N E E$ from $R_{\text {eco. }}$.

The $\mathrm{CO}_{2}$ fluxes were measured for 2 days at each site. The measurements started at noon of the first day and continued for $24 \mathrm{~h}$, every $2 \mathrm{~h}$ during the daytime and every $4 \mathrm{~h}$ during the nighttime, when there was no rainfall at the site.

\subsection{Auxiliary measurements}

Along with $\mathrm{CO}_{2}$ flux measurements, measurements inside the chamber of photosynthetically active radiation $\left(P A R_{\mathrm{c}}\right)$, air temperature $\left(T_{\mathrm{c}}\right)$, and relative humidity $\left(R H_{\mathrm{c}}\right)$ were simultaneously measured by a quantum sensor (LI-190SL, Li-Cor) and a temperature-and-humidity sensor (2119A, Eto Denki), respectively.

The soil temperature $\left(T_{\mathrm{s}}\right)$ and soil volumetric water content $(V W C)$ at a depth of $5 \mathrm{~cm}$ were measured at each site by soil-moisture-and-temperature sensors (5TM, Decagon Devices Inc., Pullman, WA, USA) and recorded at 5-min intervals by dataloggers (Em50, Decagon Devices).

Plant species composition within each collar was recorded. The number of plant species that covered more than $1 \%$ of each area enclosed by collars was counted. Live aboveground green biomass $(A G B)$ was measured by clipping green parts of the vegetation in each collar at the end of each observation period. Clipped plant samples were oven dried at $80{ }^{\circ} \mathrm{C}$ for 48 $\mathrm{h}$ and then weighed.

Soil samples were collected at each site after $\mathrm{CO}_{2}$ flux measurements and were air dried and sieved to 2 $\mathrm{mm}$ and $0.5 \mathrm{~mm}$ for chemical analyses. Soil organic carbon $(S O C)$ content was measured with the Tyurin titrimetric method by digestion with a mixture of $\mathrm{K}_{2} \mathrm{Cr}_{2} \mathrm{O}_{7}$ and $\mathrm{H}_{2} \mathrm{SO}_{4}$ (Committee of Soil Standard Methods for Analyses and Measurements, 1986). Total nitrogen $(T N)$ content was determined by dry combustion with an elemental analyzer (FLASH2000, Thermo Fisher Scientific Inc., Waltham, MA, USA). Particle size distribution was determined by the pipette method after oxidation of organic matter with $\mathrm{H}_{2} \mathrm{O}_{2}$ and elimination of carbonates with $\mathrm{HCl}$ (Committee of Soil Environment Analysis, 1997).

\subsection{Data analysis}

To remove the effects of temporal changes in radiation and temperature, GPP and $R_{\text {eco }}$ were fitted to lightand temperature-response curves. The relationship between $G P P$ and $P A R$ was described by a rectangular hyperbola light-response function forced through zero (Michaelis and Menten, 1913):

$$
G P P=\frac{P_{\max } \alpha Q_{\mathrm{p}}}{\alpha Q_{\mathrm{p}}+P_{\max }},
$$

where $Q_{\mathrm{p}}$ is incident $P A R, P_{\max }$ is maximum GPP at infinite light, and $\alpha$ is the initial slope of the lightresponse curve (also called the apparent quantum yield). Ecosystem respiration data from each set of measurements were fitted to the following equation (van't Hoff-type model) :

$$
R_{\text {eco }}=R_{20} Q_{10}{ }^{\left(T_{\mathrm{s}}-T_{\text {ref }}\right) / 10},
$$

where $R_{20}$ is the standardized rate of respiration ( $\mu \mathrm{mol}$ $\left.\mathrm{m}^{-2} \mathrm{~s}^{-1}\right)$ at the reference temperature $\left(=20{ }^{\circ} \mathrm{C}\right), Q_{10}$ is the factor by which respiration rate increases for a $10{ }^{\circ} \mathrm{C}$ increment of temperature (dimensionless), $T_{\mathrm{s}}$ is soil temperature $\left({ }^{\circ} \mathrm{C}\right)$ at a depth of $5 \mathrm{~cm}$, and $T_{\text {ref }}$ is the reference temperature of $20{ }^{\circ} \mathrm{C}$. In our measurements, the soil temperature varied from approximately $10{ }^{\circ} \mathrm{C}$ to $30{ }^{\circ} \mathrm{C}$, indicating that $20{ }^{\circ} \mathrm{C}$ was the center of the temperature range. To compare sites, the $P_{\max }, \alpha, R_{20}$, and $Q_{10}$ values were calculated for each collar and averaged for each site.

We used the coefficient of variation $(\mathrm{CV})$ of each variable to characterize the magnitude of its spatial variation. The $C V$ is given by

$$
\mathrm{CV}=\frac{\sigma}{\bar{x}} 100
$$

where $\sigma$ and $\bar{x}$ are the standard deviation and mean, respectively, of the variable.

The relationships between environmental parameters and $G P P$ and $R_{\text {eco }}$ values were analyzed using nonparametric correlations and linear and nonlinear regressions. Relationships were judged to be significant if the type I error rate was $5 \%$ or less. All statistical and regression analyses were performed with ORIGINPRO 8.1 (OriginLab, Northampton, MA, USA) .

\section{Results}

3.1 Parameters that characterize GPP and $R_{\text {eco }}$ and environmental properties 
Table 2. Soil and plant properties at the measurement sites.

\begin{tabular}{|c|c|c|c|c|c|c|c|c|c|}
\hline Site & BU-NG & BU-G1 & SB1 & NB & BU-G2 & SB2 & DT & BT & BJ \\
\hline \multicolumn{10}{|l|}{ Soil texture } \\
\hline Sand $(\%)$ & 85.4 & 93.1 & 69.5 & 54.8 & 87.5 & 83.1 & 70.5 & 75.9 & 76.8 \\
\hline Silt $(\%)$ & 9.1 & 2.6 & 14.8 & 24.8 & 5.8 & 8.7 & 11.2 & 11.3 & 11.6 \\
\hline Clay $(\%)$ & 5.5 & 4.3 & 15.7 & 20.4 & 6.8 & 8.3 & 18.3 & 12.9 & 11.7 \\
\hline SOC $\left(\mathrm{g} \mathrm{kg}^{-1}\right)$ & 8.84 & 7.10 & 11.88 & 23.25 & 6.67 & 7.69 & 7.91 & 8.13 & 13.19 \\
\hline $\mathrm{TN}\left(\mathrm{g} \mathrm{kg}^{-1}\right)$ & 0.95 & 0.85 & 1.10 & 2.32 & 0.75 & 0.86 & 0.98 & 0.98 & 1.31 \\
\hline $\mathrm{C} / \mathrm{N}$ ratio & 9.30 & 8.35 & 10.80 & 10.04 & 8.89 & 8.93 & 8.04 & 8.30 & 10.08 \\
\hline $\operatorname{VWC}\left(\mathrm{m}^{3} \mathrm{~m}^{-3}\right)$ & 0.055 & 0.184 & 0.162 & 0.205 & 0.140 & 0.067 & 0.079 & 0.045 & 0.117 \\
\hline $\mathrm{AGB}^{\dagger}\left(\mathrm{g} \mathrm{dw} \mathrm{m}^{-2}\right)$ & 59.7 & 78.4 & 55.5 & 105.2 & 94.4 & 49.5 & 78.1 & 119.9 & 182.5 \\
\hline $\mathrm{PSN}^{\dagger}$ & 2.50 & 2.75 & 2.25 & 4.25 & 3.00 & 2.25 & 1.67 & 2.67 & 4.33 \\
\hline $\begin{array}{l}\text { Plant species } \\
\text { composition }^{\dagger \dagger}\end{array}$ & $\mathrm{a}, \mathrm{f}, \mathrm{g}, \mathrm{l}$ & $\begin{array}{c}\mathrm{a}, \mathrm{f}, \mathrm{g} \\
\mathrm{h}, \mathrm{k}\end{array}$ & $a, e, f$ & $\begin{array}{c}\text { a, e, f, } \\
h, i, j, 1\end{array}$ & $\begin{array}{l}\mathrm{a}, \mathrm{d}, \mathrm{f} \\
\mathrm{g}, \mathrm{h}, \mathrm{k}\end{array}$ & $\begin{array}{c}a, b, g \\
\text { h, l }\end{array}$ & $\mathrm{c}, \mathrm{f}, \mathrm{h}$ & $\begin{array}{c}\mathrm{c}, \mathrm{d}, \mathrm{f}, \\
\mathrm{h}, \mathrm{l}\end{array}$ & $\begin{array}{c}a, f, g \\
h, j\end{array}$ \\
\hline
\end{tabular}

SOC, soil organic carbon; $\mathrm{TN}$, total nitrogen; $\mathrm{C} / \mathrm{N}$, carbon-nitrogen ratio; VWC, soil volumetric water content; AGB, aboveground green biomass; PSN, plant species number.

${ }^{\dagger}$ AGB and PSN are the average values of the three or four collars for each site.

${ }^{\dagger \dagger}$ a, Artemisia spp.; b, Agropyron cristatum; c, Allium tenuissimum; d, Caragana spp.; e, Carex spp.; f, Chenopodium spp.; g, Cleistogenes squarrosa; h, Elymus chinensis; i, Heteropappus hispidus; j, Potentilla acaulis; k, Salsola ruthenica; 1, Stipa krylovii.

The average values of the parameters that characterize $G P P$ and $R_{\text {eco }}\left(P_{\max }, \alpha, R_{20}\right.$, and $\left.Q_{10}\right)$ for each site are shown in Figure 3. The values of $P_{\max }$ and $\alpha$ varied from 8.6 to $29.9 \mu \mathrm{mol} \mathrm{m}^{-2} \mathrm{~s}^{-1} \quad(C V=46.9 \%)$ and from 0.014 to $0.046 \mu \mathrm{mol} \mathrm{CO}_{2} \mu \mathrm{mol}^{-1}$ photons $(\mathrm{CV}=$ $46.3 \%$ ), respectively. The $R_{20}$ and $Q_{10}$ values varied from 1.7 to $6.9 \mu \mathrm{mol} \mathrm{m} \mathrm{m}^{-2} \mathrm{~s}^{-1}(C V=44.3 \%)$ and from 1.5 to $2.5(C V=18.0 \%)$, respectively. All the parameters differed significantly among the sites (one-way ANOVA, $p<0.001$ for $P_{\max }, R_{20}$, and $Q_{10} ; p=0.007$ for $\alpha$ ). The fact that $P_{\max }$ and $R_{20}$ values were strongly correlated with each other (Spearman's rank correlation coefficient, $r_{\mathrm{s}}=0.92$; Table 3) suggests that spatial patterns of ecosystem $\mathrm{CO}_{2}$ uptake and respiratory release were quite similar.

The soil and plant parameters measured at the nine sites are summarized in Table 2. Whereas the sand fraction was high at all the sites, site NB was characterized by higher silt and clay fractions than the other sites. The fact that the levels of SOC and $T N$ were positively correlated with the fractions of silt and clay (Table 3) resulted in higher $S O C$ and $T N$ values at site $\mathrm{NB}$ than at the other sites. The values of $V W C$ and $A G B$ differed greatly between the sites. In general, vegetation activity is strongly correlated with soil moisture in Mongolia (Iwasaki, 2006; Nandintsetseg et al., 2010), but we found no significant correlation between $V W C$ and $A G B$ (Table 3) . Long-term averages of summer precipitation (Table 1) were linearly correlated with $A G B$ values (Pearson's correlation coefficient, $r=0.87$ ), but there was no relationship between $V W C$ values and summer precipitation. Because the measurements were conducted in a short time span (24 h at each site), our VWC data should reflect short-term temporal variations rather than long-term spatial characteristics.

\subsection{Factors controlling the spatial variation of $\mathrm{CO}_{2}$ exchanges}

Rank correlation coefficients $\left(r_{\mathrm{s}}\right)$ among the GPP and $R_{\text {eco }}$ parameters and the plant and soil properties that we used to characterize the spatial differences between the environments of the sites are listed in Table 3. Strong relationships were found between $P_{\max }$ and $R_{20}$ and $A G B$ and plant species number $(P S N)$, indicating that the greater rates of $\mathrm{CO}_{2}$ uptake and release were caused by enhanced plant growth and productivity. Apparent quantum yield $(\alpha)$ was also significantly related to $A G B$. In contrast, $Q_{10}$ showed a significant relationship only with soil $V W C$.

Both $P_{\max }$ and $R_{20}$ were well described as linear functions of $A G B$ (Fig. 4). To separate the combined effects of $A G B$ and other factors, we calculated $P_{\max }$ 

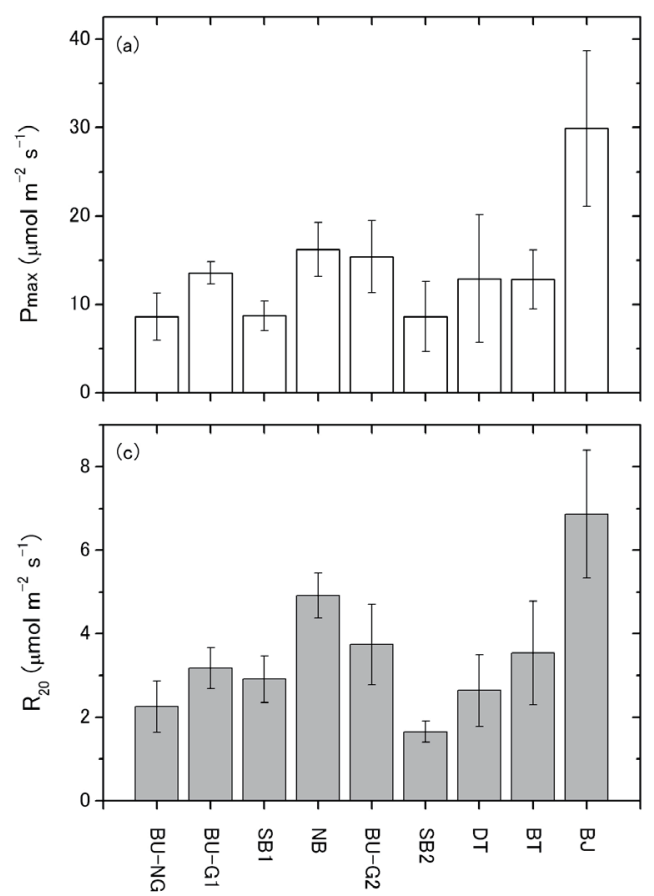
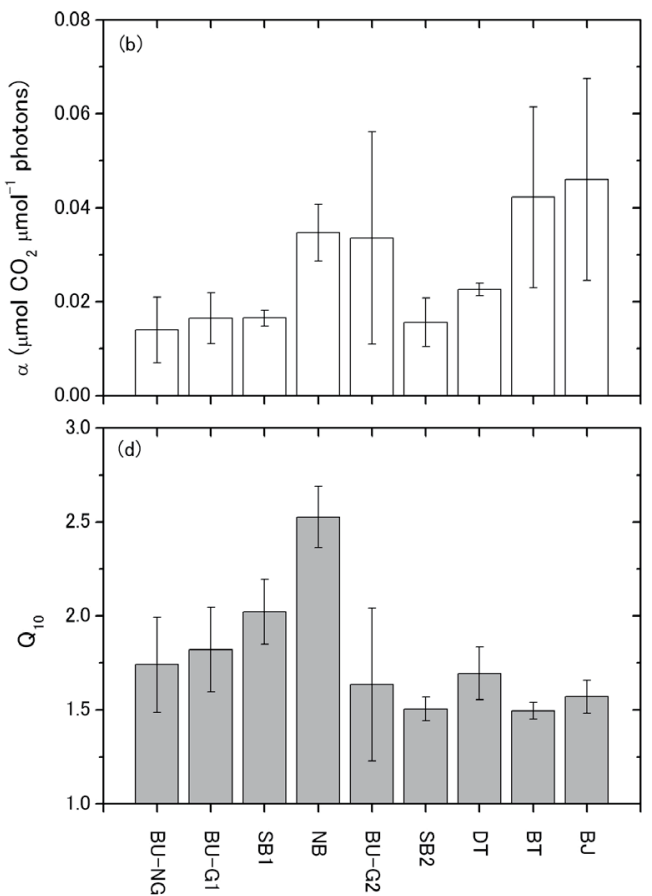

Fig. 3. Site-averaged values of (a) $P A R$-saturated $G P P\left(P_{\max }\right)$, (b) apparent quantum yield of $G P P(\alpha)$, (c) standardized rates of $R_{\text {eco }}$ at $20{ }^{\circ} \mathrm{C}\left(R_{20}\right)$, and (d) temperature sensitivity of $R_{\text {eco }}\left(Q_{10}\right)$. Bars indicate standard deviations.

normalized by the amount of $A G B\left(P_{\max } / A G B\right.$ [ $\mu \mathrm{mol}$ $\left.\mathrm{g} \mathrm{dw}^{-1} \mathrm{~s}^{-1}\right]$ ) and the $R_{20}$ residuals, which are the differences between the measured values and the values estimated by the linear model in Figure $4 \mathrm{~b}$. The $R_{20}$ residuals differed significantly among the sites $(p=$ $0.002)$, whereas the $P_{\max } / A G B$ ratio did not differ $(p=$ 0.58 ) (Fig. 5). The relationships between $P_{\max } / A G B$ ratios and $R_{20}$ residuals and soil properties are shown in Figure 6 . The $R_{20}$ residuals were significantly related to $V W C\left(r_{\mathrm{s}}=0.83 ; p=0.005\right)$ and $\mathrm{C} / \mathrm{N}$ ratios $\left(r_{\mathrm{s}}=\right.$ $0.73 ; p=0.025)$, whereas $P_{\max } / A G B$ ratios were not significantly related to any soil parameters.

\section{Discussion}

In the present study, $G P P$ and $R_{\text {eco }}$ varied greatly $\left(C V=46.9 \%\right.$ for $P_{\max } ; C V=44.3 \%$ for $\left.R_{20}\right)$ among the nine Mongolian semiarid grassland sites, although all of the sites are located in the same climate (semiarid) and the same vegetation (temperate grassland) zone (Figs.1 and 2). A few studies have reported within-grassland spatial variation in the rates of GPP and
$R_{\text {eco }}$ and have demonstrated that both fluxes vary markedly among sites. Risch and Frank (2006) measured $\mathrm{CO}_{2}$ fluxes at seven grassland sites in the northern winter range $(100,000$ ha) of Yellowstone National Park, USA. They indicated that the greatest fluxes among the sites were four to five times the lowest fluxes. The $C V$ values that we calculated from their data were $50.2 \%$ for $G P P$ and $49.9 \%$ for $R_{\text {eco. }}$. Petrone et al. (2008) measured NEE, GPP, and $R_{\text {eco }}$ at three grassdominated sites within a small catchment $(500 \mathrm{~m} \times$ $500 \mathrm{~m})$ in Ontario, Canada, and reported $C V$ values for $G P P$ and $R_{\text {eco }}$ of $18 \%$ and $20 \%$, respectively. Hirota et al. (2010) also measured NEE, GPP, and $R_{\text {eco }}$ at 14 points in a small area $(30 \mathrm{~m} \times 40 \mathrm{~m})$ in an alpine meadow on the Qinghai-Tibetan Plateau, China, and determined $P_{\max }, \alpha, R_{20}$, and $Q_{10}$. They reported that $C V$ values for $P_{\max }$ and $R_{20}$ were $29.4 \%$ and $27.3 \%$, respectively. Thus, because the spatial variability of $G P P$ and $R_{\text {eco }}$ are large, even within a grassland, it is essential to take their variability into account when estimating regional carbon budgets. 
Our results demonstrated that spatial variations in $A G B$ and $P S N$ were the best predictors of the variability of photosynthetic uptake and respiratory release of $\mathrm{CO}_{2}$ (Table 3). Other studies have reported similar spatial relationships between $G P P$ and $A G B$ (Risch and Frank, 2006; Petrone et al., 2008), between $P_{\max }$ and $P S N$ (Hirota et al., 2010), and between $R_{\text {eco }}$ and $A G B$ (Risch and Frank, 2006; Petrone et al., 2008). As for temporal variability, many studies have shown a strong relationship between $G P P$ and the amount of growing plant tissue, represented by indices such as the leaf area index (LAI) or $A G B$ (Frank and Dugas, 2001; Flanagan et al., 2002; Byrne et al., 2005; Aires et al., 2008; Nakano et al., 2008). Our results showed that $A G B$ was related to not only $G P P$, but also $R_{\text {eco }}$. Several recent studies have indicated that plant productivity associated with either $A G B$ or $L A I$ is the dominant control on the magnitude of ecosystem and soil respiration in grasslands (Craine et al., 1999; Xu and Baldocchi, 2004; Bahn et al., 2008; Zhang et al., 2009; Nakano and Shinoda, 2010). This relationship reflects the fact that photosynthetic productivity has a strong influence on the activity of roots and associated organisms (Moyano et al., 2008) and the belowground supply of labile carbon (Sampson et al., 2007). Hirota et al. (2010) reported that PSN correlated positively with $G P P$, but not with $R_{\text {eco }}$ and explained that the relationship might be attributable to interspecies differences in photosynthetic light use efficiencies of leaves. In the present study, we found a significant correlation between $P S N$ and both $G P P$ and $R_{\text {eco }}$, and between $P S N$ and $A G B$ (Table 3). The relationship between $P S N$ and the $\mathrm{CO}_{2}$ exchanges could therefore be apparent, a result of the dependency of the number of species on $A G B$. To understand the effect of the number of species on $\mathrm{CO}_{2}$ exchanges, further investigations will be

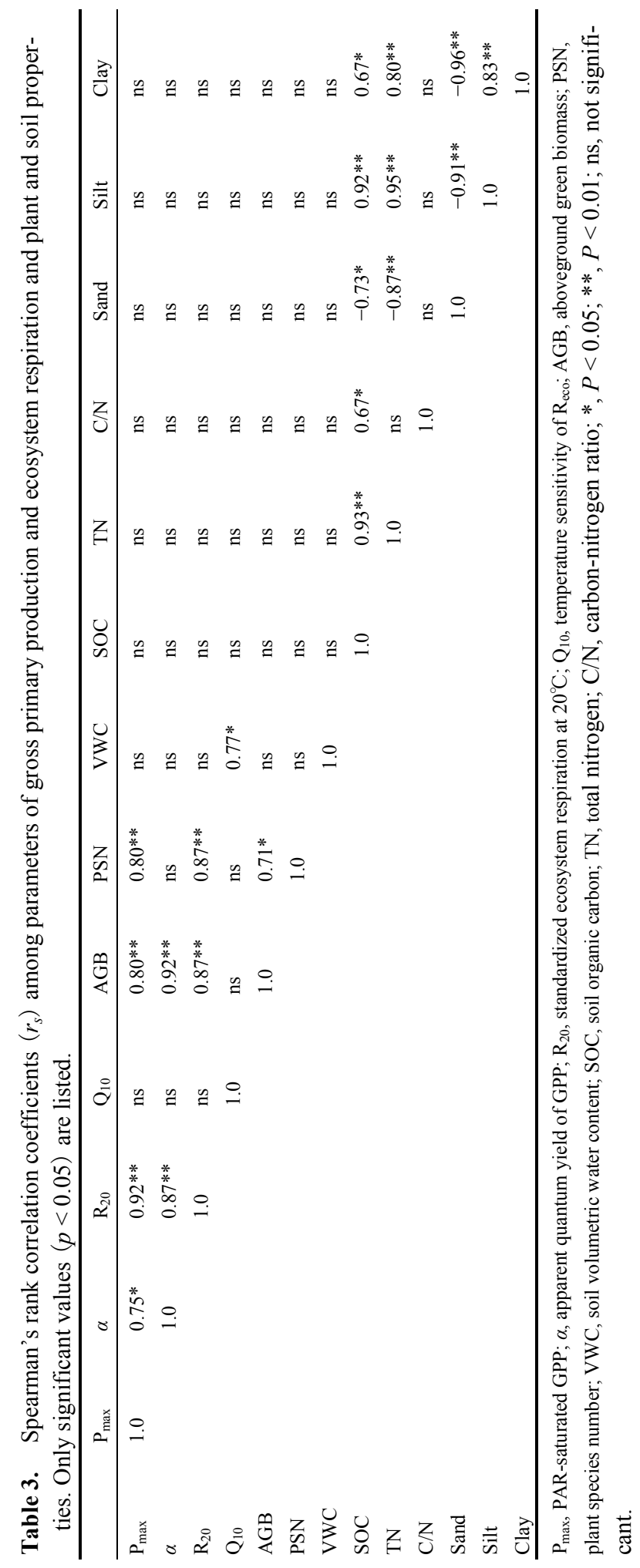



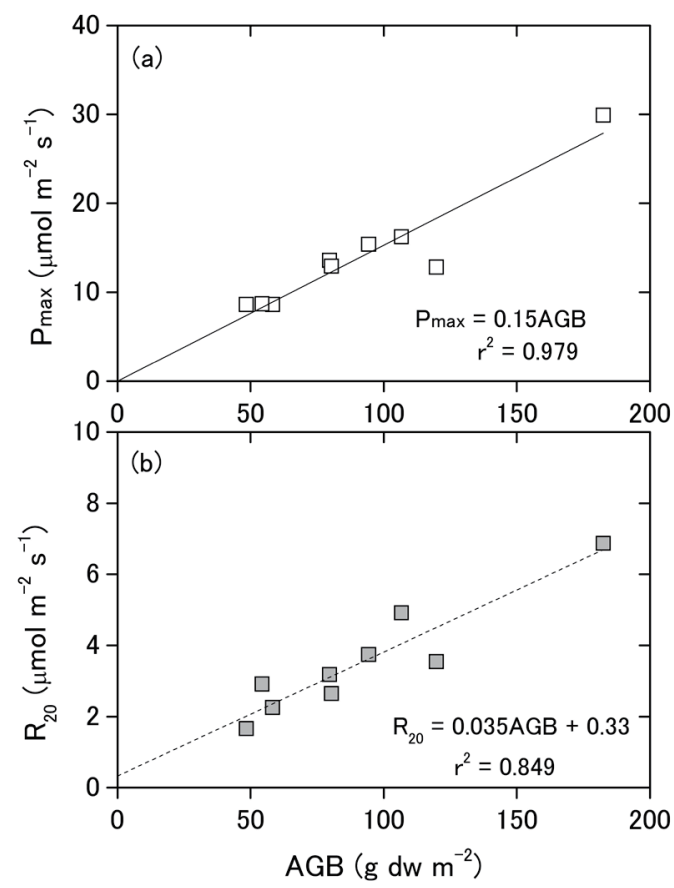

Fig. 4. The relationships between aboveground green biomass $(A G B)$ and (a) PAR-saturated $G P P\left(P_{\max }\right)$, and $(\mathrm{b})$ standardized rates of $R_{\text {eco }}$ at $20{ }^{\circ} \mathrm{C}\left(R_{20}\right)$.

needed.

The temperature sensitivity of $R_{\text {eco }}\left(Q_{10}\right)$ was positively correlated with soil $V W C$ in this study. This result is in agreement with several recent studies suggesting that $Q_{10}$ declines with decreasing water availability (Reichstein et al., 2002; Flanagan and Johnson, 2005; Aires et al., 2008; Li et al., 2008).

After removing the contribution of $A G B$ to the spatial variability of $G P P$ and $R_{\text {eco }}$, we examined the relationship between soil characteristics and $P_{\max } / A G B$ ratios and $R_{20}$ residuals (Fig. 6). Our analysis indicated that there were significant positive correlations between $R_{20}$ residuals and $V W C$ and $\mathrm{C} / \mathrm{N}$ ratios, although $P_{\max } / A G B$ ratios were unrelated to any soil parameters. Several studies have indicated that soil water is an important variable that controls the rate of ecosystem respiration in grasslands (Hunt et al., 2002; Byrne et al., 2005; Flanagan and Johnson, 2005; Kjelgaard et al., 2008). Some studies have shown a positive linear or exponential relationship between standardized $R_{\text {eco }}$ at a reference temperature and soil mois-
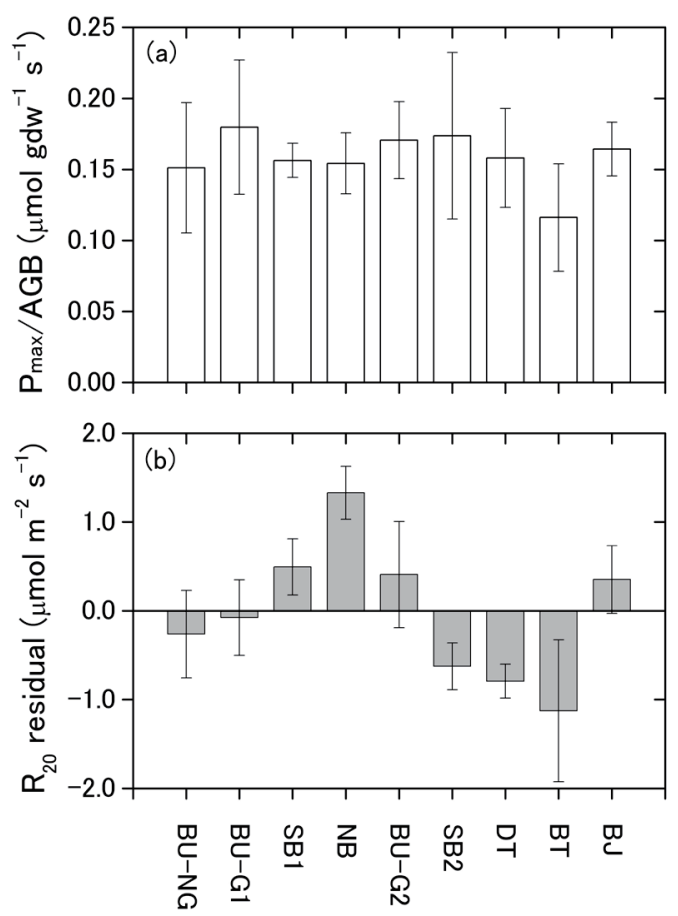

Fig. 5. Site-averaged values of (a) $P A R$-saturated $G P P$ normalized to aboveground green biomass $\left(P_{\max } / A G B\right)$, and (b) $R_{20}$ residuals of the linear biomass model. Bars indicate standard deviations.

ture (Hunt et al., 2002; Flanagan and Johnson, 2005; Kjelgaard et al., 2008; Jia et al., 2012), and others have found that there is an optimum soil moisture content at which the rate of ecosystem and soil respiration peaks (Byrne et al., 2005; Wen et al., 2006; Jassal et al., 2008).

Although very few studies have assessed the effect of soil nutrient levels on ecosystem respiration, there have been many studies of soil nutrient level effects on soil respiration $\left(R_{\mathrm{s}}\right)$. These studies have reported a positive relationship between $R_{\mathrm{S}}$ and soil organic carbon content (Tufekcioglu et al., 2001; Bahn et al., 2008), a positive relationship between $R_{\mathrm{s}}$ and nitrogen content (Petrone et al., 2008), a negative relationship between $R_{\mathrm{S}}$ and the $\mathrm{C} / \mathrm{N}$ ratio (Khomik et al., 2006; Petrone et al., 2008; Qi et al., 2010), and a positive relationship between $R_{\mathrm{s}}$ and the $\mathrm{C} / \mathrm{N}$ ratio (Ngao et al., 2012). Peng et al. (2010) and Jia et al. (2012) carried out nitrogen-fertilization experiments in a temperate grassland and in a semiarid grassland of China, respectively. They found that nitrogen addition significantly 


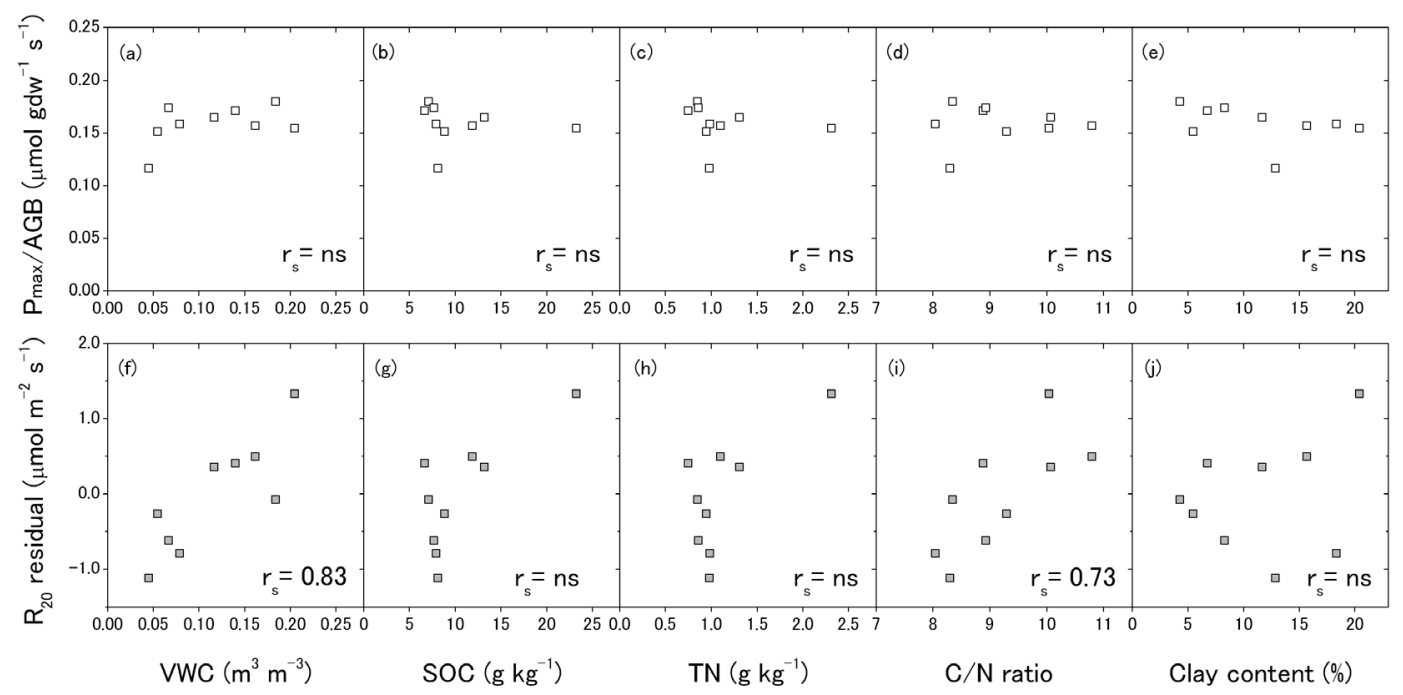

Fig. 6. The relationships between $P A R$-saturated $G P P$ normalized to aboveground green biomass $\left(P_{\max } / A G B\right)$ and (a) volumetric water content $(V W C)$, (b) soil organic carbon content $(S O C)$, (c) total nitrogen content $(T N)$, (d) carbon/nitrogen $(\mathrm{C} / \mathrm{N})$ ratio, and (e) clay content, and between $R_{20}$ residuals of the linear biomass model and (f) $V W C$, (g) $S O C$, (h) $T N$, (i) $\mathrm{C} / \mathrm{N}$ ratio, and (j) clay content. $r_{\mathrm{s}}$, Spearman's rank correlation coefficient; ns, not significant.

increased soil $\mathrm{CO}_{2}$ emissions compared with a control plot. Studies conducted with forest soils have indicated that soil microorganisms prefer substrates that are high in nitrogen (or have a low $\mathrm{C} / \mathrm{N}$ ratio). Thus, in areas where the litter $\mathrm{C} / \mathrm{N}$ ratio is low, one would expect higher $R_{\mathrm{S}}$ as a result of increased decomposition activity (Khomik et al., 2006; Vesterdal et al., 2008). Contrary to those findings, we found a positive relationship between $R_{20}$ residuals and $\mathrm{C} / \mathrm{N}$ ratios in our study. Ngao et al. (2012) also showed a positive correlation between $R_{\mathrm{s}}$ values and $\mathrm{C} / \mathrm{N}$ ratios in a temperate beech forest in France. They mentioned that the positive relationship they observed probably reflected better carbon consumption efficiency with increasing $\mathrm{C} / \mathrm{N}$ ratios under nonlimiting nitrogen conditions. Although the exact reason for the positive relationship in our study is difficult to explain, it might imply that soil carbon content is more of a limiting factor than nitrogen content in semiarid grasslands.

\section{Conclusion}

The present study revealed large spatial variability of $\mathrm{CO}_{2}$ fluxes within semiarid Mongolian grassland ecosystems, despite similarities of climate and vegeta- tion. Spatial variations in plant photosynthetic production were closely associated with variations in vegetation properties such as plant aboveground green biomass and numbers of species. Spatial patterns of ecosystem respiration were primarily related to vegetation properties and secondarily to soil water content and $\mathrm{C} / \mathrm{N}$ ratios. Thus, our study suggests that understanding the spatial heterogeneity of ecosystem $\mathrm{CO}_{2}$ exchanges will be important if estimates of carbon budgets are to be improved at regional scales.

\section{Acknowledgments}

We thank Ganbat Bavuudorj of the Institute of Meteorology, Hydrology, and Environment of Mongolia for his help in field measurements. This research was funded by the Ministry of Education, Culture, Sports, Science and Technology of Japan (Grant-in-Aid no. 22510017).

\section{References}

Aires, L. M. I., Pio, C. A., and Pereira, J. S., 2008: Carbon dioxide exchange above a Mediterranean $\mathrm{C} 3 / \mathrm{C} 4$ grassland during two climatologically contrasting years. Global Change Biology, 14, 539-555. 
Bahn, M., Rodeghiero, M., Anderson-Dunn, M., Dore, S., Gimeno, C., Drösler, M., Williams, M., Ammann, C., Berninger, F., Flechard, C., Jones, S., Balzarolo, M., Kumar, S., Newesely, C., Priwitzer, T., Raschi, A., Siegwolf, R., Susiluoto, S., Tenhunen, J., Wohlfahrt, G., and Cernusca1, A., 2008: Soil respiration in European grasslands in relation to climate and assimilate supply. Ecosystems, 11, 1352-1367.

Byrne, K. A., Kiely, G., and Leahy, P., 2005: $\mathrm{CO}_{2}$ fluxes in adjacent new and permanent temperate grassland. Agricultural and Forest Meteorology, 135, $82-92$.

Committee of Soil Environment Analysis, 1997: Methods for Soil Environment Analysis. Hakuyusha, Tokyo, 427pp. (in Japanese)

Committee of Soil Standard Methods for Analyses and Measurements, 1986: Soil Standard Methods for Analyses and Measurements. Hakuyusha, Tokyo, 354pp. (in Japanese)

Craine, J. M., Wedin, D. A., and Chapin III, F. S., 1999: Predominance of ecophysiological controls on soil $\mathrm{CO}_{2}$ flux in a Minnesota grassland. Plant and Soil, 207, 77-86.

Flanagan, L. B. and Johnson, B. G., 2005: Interacting effects of temperature, soil moisture and plant biomass production on ecosystem respiration in a northern temperate grassland. Agricultural and Forest Meteorology, 130, 237-253.

Flanagan, L. B., Wever, L. A., and Carlson, P. J., 2002: Seasonal and interannual variation in carbon dioxide exchange and carbon balance in a northern temperate grassland. Global Change Biology, 8, 599-615.

Frank, A. B. and Dugas, W. A., 2001: Carbon dioxide fluxes over a northern, semiarid, mixed-grass prairie. Agricultural and Forest Meteorology, 108, 317-326.

Hijmans, R. J., S. E. Cameron, J. L. Parra, P. G. Jones and A. Jarvis, 2005: Very high resolution interpolated climate surfaces for global land areas. International Journal of Climatology, 25, 1965-1978.

Hirota, M., Zhang, P., Gu, S., Shen, H., Kuriyama, T., Li, Y., and Tang, Y., 2010: Small-scale variation in ecosystem $\mathrm{CO}_{2}$ fluxes in an alpine meadow depends on plant biomass and species richness. Journal of Plant Research, 123, 531-541.

Hunt, J. E., Kelliher, F. M., McSeveny, T. M., and Byers, J. N., 2002: Evaporation and carbon dioxide exchange between the atmosphere and a tussock grassland during a summer drought. Agricultural and Forest Meteorology, 111, 65-82.

IUSS Working Group WRB, 2006: World reference base for soil resources 2006. 2nd edition. World Soil References Reports 103, FAO, Rome, 128pp.

Iwasaki, H., 2006: Impact of interannual variability of meteorological parameters on vegetation activity over Mongolia. Journal of the Meteorological Society of Japan, 84, 745-762.

Jassal, R. S., Black, T. A., Novak, M. D., GaumontGuay, D., and Nesic, Z., 2008: Effect of soil water stress on soil respiration and its temperature sensitivity in an 18-year-old temperate Douglas-fir stand. Global Change Biology, 14, 1-14.

Jia, X., Shao, M., and Wei, X., 2012: Responses of soil respiration to $\mathrm{N}$ addition, burning and clipping in temperate semiarid grassland in northern China. $\mathrm{Ag}$ ricultural and Forest Meteorology, 166-167, 32-40.

Kato, T. and Tang, Y., 2008: Spatial variability and major controlling factors of $\mathrm{CO}_{2}$ sink strength in Asian terrestrial ecosystem: evidence from eddy covariance data. Global Change Biology, 14, 23332348.

Khomik, M., Arain, M. A., and McCaughey, J. H., 2006: Temporal and spatial variability of soil respiration in a boreal mixedwood forest. Agricultural and Forest Meteorology, 140, 244-256.

Kjelgaard, J. F., Heilman, J. L., McInnes, K. J., Owens, M. K., and Kamps, R. H., 2008: Carbon dioxide exchange in a subtropical, mixed $\mathrm{C} 3 / \mathrm{C} 4$ grassland on the Edwards Plateau, Texas. Agricultural and Forest Meteorology, 148, 953-963.

Li, H., Yan, J., Yue, X., and Wang, M., 2008: Significance of soil temperature and moisture for soil respiration in a Chinese mountain area. Agricultural and Forest Meteorology, 148, 490-503.

Maestre, F. T., and Cortina, J. 2003: Small-scale spatial variation in soil $\mathrm{CO}_{2}$ efflux in a Mediterranean semiarid steppe. Applied Soil Ecology, 23, 199-209.

Michaelis, L. and Menten, M. L., 1913: Die Kinetik der Invertinwirkung. Biochemische Zeitschrift, 49, 333-369.

Moyano, F. E., Kutsch, W. L., and Rebmann, C., 2008: Soil respiration fluxes in relation to photosynthetic activity in broad-leaf and needle-leaf forest stands. Agricultural and Forest Meteorology, 148, 135-143.

Nakano, T. and Shinoda, M., 2010: Response of ecosystem respiration to soil water and plant biomass in a semiarid grassland. Soil Science and Plant Nutrition, 56, 773-781.

Nakano, T., Nemoto, M., and Shinoda, M., 2008: Environmental controls on photosynthetic production and ecosystem respiration in semi-arid grasslands of Mongolia. Agricultural and Forest Meteorology, 148, 1456-1466.

Nakano, T., Bavuudorj, G., Urianhai, N. G., and Shinoda, M., 2013: Monitoring aboveground biomass in semiarid grasslands using MODIS images. Journal of Agricultural Meteorology, 69, 23-29.

Nandintsetseg, B., Shinoda, M., Kimura, R., and Ibaraki, Y., 2010: Relationship between soil mois- 
ture and vegetation activity in the Mongolian steppe. SOLA, 6, 29-32.

Ngao, J., Epron, D., Delpierre, N., Bredaa, N., Granier, A., and Longdoz, B., 2012: Spatial variability of soil $\mathrm{CO}_{2}$ efflux linked to soil parameters and ecosystem characteristics in a temperate beech forest. Agricultural and Forest Meteorology, 154-155, 136-146.

Peng, Q., Dong, Y., Qi, Y., Xiao, S., He, Y., and Ma, T., 2010: Effects of nitrogen fertilization on soil respiration in temperate grassland in Inner Mongolia, China. Environmental Earth Sciences, DOI 10.1007/s12665-010-0605-4.

Petrone, R. M., Chahil, P., Macrae, M. L., and English, M. C., 2008: Spatial variability of $\mathrm{CO}_{2}$ exchange for riparian and open grasslands within a first-order agricultural basin in Southern Ontario. Agriculture, Ecosystems \& Environment, 125, 137-147.

Qi, Y. C., Dong, Y. S., Jin, Z., Peng, Q., Xiao, S. S. and He, Y. T., 2010: Spatial heterogeneity of soil nutrients and respiration in the desertified grasslands of Inner Mongolia, China. Pedosphere, 20, 655-665.

Reichstein, M., Tenhunen, J. D., Roupsard, O., Ourcival, J.-M., Rambal, S., Dore, S., and Valentini, R., 2002: Ecosystem respiration in two Mediterranean evergreen Holm Oak forests: drought effects and decomposition dynamics. Functional Ecology, 16, 2739.

Risch, A. C. and Frank D. A., 2006: Carbon dioxide fluxes in a spatially and temporally heterogeneous temperate grassland. Oecologia, 147, 291-302.

Sampson, D. A., Janssens, I. A., Curiel Yuste, J., and Ceulemans, R., 2007: Basal rates of soil respiration are correlated with photosynthesis in a mixed temperate forest. Global Change Biology, 13, 20082017.

Shinoda, M., Nachinshonhor, G. U., and Nemoto, M., 2010: Impact of drought on vegetation dynamics of the Mongolian Steppe: a field experiment. Journal of Arid Environments, 74, 63-69.

Tufekcioglu, A., Raich, J. W., Isenhart, T. M., and Schultz, R. C., 2001: Soil respiration within riparian buffers and adjacent crop fields. Plant and Soil, 229, 117-124.
UNEP, 1997: World atlas of desertification 2nd edition. UNEP, London, 182pp.

Vesterdal, L., Schmidt, I. K., Callesen, I., Nilsson, L. O., and Gundersen, P., 2008: Carbon and nitrogen in forest floor and mineral soil under six common European tree species. Forest Ecology and Management, 255, 35-48.

Wen, X. F., Yu, G. R., Sun, X. M., Li, Q. K., Liu,Y. F., Zhang, L. M., Ren, C. Y., Fu, Y. L., and Li, Z. Q., 2006: Soil moisture effect on the temperature dependence of ecosystem respiration in a subtropical Pinus plantation of southeastern China. Agricultural and Forest Meteorology, 137, 166-175.

Xu, L. and Baldocchi, D. D., 2004: Seasonal variation in carbon dioxide exchange over a Mediterranean annual grassland in California. Agricultural and Forest Meteorology, 123, 79-96.

Yu, G., Zhu, X., Fu, Y., He, H., Wang, Q., Wen, X., Li, X., Zhang, L., Zhang, L., Su, W., Li, S., Sun, X., Zhang, Y., Zhang, J., Yan, J., Wang, H., Zhou, G., Jia, B., Xiang, W., Li, Y., Zhao, L., Wang, Y., Shi, P., Chen, S., Xin, X., Zhao, F., Wang, Y., and Tong, C., 2013: Spatial patterns and climate drivers of carbon fluxes in terrestrial ecosystems of China. Global Change Biology, 19, 798-810.

Yuan, W., Luo, Y., Richardson, A. D., Oren, R., Luyssaert, S., Janssens, I. A., Ceulemans, R., Zhou, X., Grunwald, T., Aubinet, M., Berhofer, C., Baldocchi, D. D., Chen, J., Dunn, A. L., Deforest, J. L., Dragoni, D., Goldstein, A. H., Moors, E., Munger, J. W., Monson, R. K., Suyker, A. E., Starr, G., Scott, R. L., Tenhunen, J., Verma, S. B., Vesala, T., and Wofsy, S. C., 2009: Latitudinal patterns of magnitude and interannual variability in net ecosystem exchange regulated by biological and environmental variables. Global Change Biology, 15, 2905-2920.

Zhang, P., Tang, Y., Hirota, M., Yamamoto, A., and Mariko, S., 2009: Use of a regression method to partition sources of ecosystem respiration in an alpine meadow. Soil Biology \& Biochemistry, 41, 663-670. 